\title{
'The very deceitfulness of devils': Firmilian and the Doubtful Baptisms of a Woman possessed by Demons
}

\author{
Charlotte Methuen* \\ University of Glasgow
}

\begin{abstract}
In the mid-third century, a controversy relating to the validity of baptism by the lapsed broke out between Cyprian, bishop of Carthage, and Stephen, bishop of Rome. The former maintained that baptisms carried out by those who later lapsed had no validity, but must be repeated by a priest of whose behaviour there could be no doubt. Stephen maintained that baptisms carried out in the name of the Father, the Son and the Holy Spirit were to be viewed as valid, whoever had carried them out. Cyprian appealed to his fellow bishops for support. In 256, Firmilian, bishop of Caesarea, wrote to bim outlining the case of a woman who had for some time baptized and celebrated the eucharist, but who had then been identified as being possessed by demons, casting her earlier actions into question. This essay will analyse the grounds for Firmilian's doubts about the validity of the woman's actions, his proposed response, and the way in which this episode has been used in modern debates about the ordination of women.
\end{abstract}

In the year 256, Firmilian, bishop of Caesarea, wrote to Cyprian, bishop of Carthage, about baptism. Firmilian's letter was a contribution to a heated debate about baptism which had been initiated by Cyprian. In the midst of a period of persecution, first under Decius and then under Valerian, Cyprian was seeking to establish a consensus amongst Christians concerning how baptisms by heretics should be regarded. He held that the validity of baptisms by any priest or bishop who was not recognizably a part of 'the Catholic church' was doubtful, and argued that in his own diocese candidates should only be baptized by a minister whose claim to authority had been confirmed by him as bishop. Stephen, bishop of Rome, did not agree, arguing that anyone who had been baptized in the name of the Father, the Son and the Holy Spirit should be regarded as properly baptized. Firmilian wrote in support of Cyprian, rejecting Stephen's position. ${ }^{1}$

\footnotetext{
* Theology and Religious Studies, No. 4 The Square, Glasgow, G41 2NW. E-mail: charlotte.methuen@glasgow.ac.uk.

${ }^{1}$ For a summary of the dispute between Cyprian and Stephen over rebaptism, see Maureen A. Tilley, 'When Schism becomes Heresy in Late Antiquity: Developing Doctrinal
} 
Cyprian's substantial surviving correspondence about the status of those baptized by heretics or schismatics illustrates the significant anxieties experienced by third-century Christians in relation to the status of the sacraments they had received. In Cyprian's context, this question was related to the status of the lapsed. Could the authority of someone who had not stood firm under persecution be trusted, and with it the sacraments they offered? Or did confessors - those who had held to their faith under cross-examination - have an intrinsic and superior spiritual authority which trumped that of those who had lapsed or fled? This was a particular issue for Cyprian, who had himself fled Carthage when persecution broke out, much to the detriment of his own standing amongst the confessors. ${ }^{2}$ Tensions around these questions were not yet as high in North Africa as they would become during the Diocletian persecution (303-5), which would see the rise of Donatism and its denial of the effectiveness of sacraments administered by those who had lapsed: Cyprian's discussion of the validity of baptism by heretics or schismatics laid the foundation for the position that the Donatists would later adopt. Firmilian's concerns, however, were somewhat different. Although his community too knew persecution, the role of the lapsed was not his main focus. Rather, Firmilian was engaged with a different question: how is it possible to be sure that someone's actions are inspired by the Holy Spirit? Unlike Cyprian, whose primary concern was the fallout after a period of persecution, Firmilian was confronted with a number of prophets, all of whom claimed to preach Christ, and was anxious

Deviance in the wounded Body of Christ', JECS 15 (2007), 1-21, at 7-10. For the controversy and its consequences, see also S. G. Hall, 'Stephen I of Rome and the Baptismal Controversy of 256', Bibliothèque de la Revue d'bistoire ecclésiastique 8 (1987), 78-82; Hubert Kirchner, 'Der Ketzertaufstreit zwischen Karthago und Rom und seine Konsequenzen für die Frage nach den Grenzen der Kirche', Zeitschrift für Kirchengeschichte 81 (1970), 290307. A good overview of Cyprian's writings on the question of rebaptism can be found in J. Jayakiran Sebastian, ' ... baptisma unum in ecclesia sancta ...': A Theological Appraisal of the Baptismal Controversy in the Work and the Writings of Cyprian of Carthage, Wissenschaftliche Beiträge aus Europäischen Hochschulen Reihe 1, Theologie Band 7 (Ammerbek bei Hamburg, 1997). Recent debate about the dating of some of Cyprian's key writings is not of relevance here: see Karl Shuve, 'Cyprian of Carthage's Writings from the Rebaptism Controversy: Two Revisionary Proposals reconsidered', Journal of Theological Studies 61 (2010), 627-43.

${ }^{2}$ Joseph M. Bryant, 'The Sect-Church Dynamic and Christian Expansion in the Roman Empire: Persecution, Penitential Discipline, and Schism in Sociological Perspective', British Journal of Sociology 44 (1993), 303-39, especially 324-7. For Cyprian's motivation for his behaviour, see Hugo Montgomery, 'Saint Cyprian's postponed Martyrdom', Symbolae Osloenses 63 (1988), 123-32. 
to differentiate between the influence of the true Spirit and that of demons.

This essay explores the ways in which Firmilian sought to discern true from doubtful inspiration, focusing on the example which he himself offered: that of a woman who was discovered to be possessed by a demon. The historiographical discussion of this text is particularly interesting because Firmilian's account was adduced in the twentieth century as patristic evidence against the ordination of women. Written as a contribution to one debate about doubtful ministries, Firmilian's letter has come to be seen as a witness in another. It will be argued here, however, that Firmilian's letter is not articulated in explicitly gendered terms. Nonetheless, it points towards the problems which would later be faced by women who sought to convince the doubtful of the divine nature of their inspiration.

For Firmilian, the authority of the Church was essential to the removal of doubt. At a synod at which 'very many of us' met in Iconium, he reported, 'we' - by which he seems to mean the 'elders and prelates' (seniores et praepositi), or elsewhere the 'senators' (majores natu) of the Church - 'decided that every baptism arranged for without the Church was altogether to be rejected'. ${ }^{3}$ A heretic, Firmilian thought, 'may not lawfully ordain nor lay on hands, so neither may he baptize, nor do anything in a holy or spiritual way, since he is a stranger to spiritual and deifying sanctity' (ita nec baptizare nec quicquam sancte nec spiritaliter gerere, quando alienus sit a spiritali et deifica sanctitate). ${ }^{4}$ Rather, 'all power and grace are established in the Church where the elders preside, who possess the power both of baptizing, and of imposition of hands, and of ordaining. 5 Because 'they who maintain their false prophesying against the faith of Christ cannot have Christ', ${ }^{6}$ and because 'spiritual birth cannot be without the Spirit', Paul himself, Firmilian believed, had 'baptized anew with a spiritual baptism those who had already been baptized by John before the

3 Cyprian, Epistle 75.4, 7, 19 (PL 3, cols 1153-78); an English translation is available in ANF 5, numbered as Epistle 74, online at: <http://www.ccel.org/ccel/ schaff/anf05.iv.iv.lxxiv.html>, accessed 16 July 2014. Translations are given according to ANF, modified where appropriate by the author. Firmilian presumably conducted his church life in Greek, although we only have a Latin version of his letter.

${ }^{4}$ Cyprian, Ep. 75.7.

5 Ibid.

${ }^{6}$ Ibid. 
Holy Spirit had been sent by the Lord'. ${ }^{7}$ However, he also observed that the distinction between the heretics and those of the true faith could be difficult: 'some had doubts about the baptism of those who, although they receive the new prophets, yet appear to recognize the same Father and Son with us'.

Key amongst the problematic groups known to Firmilian were the followers of Montanism or the 'New Prophecy': 'if we ask what Christ they announce, they will reply that they preach him who sent the Spirit that speaks by Montanus and Prisca? Such false prophets were not easy to identify. In particular, Firmilian recorded that he had been unsettled by the case of a woman who, in a period of local persecution and great confusion twenty-two years earlier, 'in a state of ecstasy presented herself as a prophet (prophetens se praeferret), and acted as if filled with the Holy Ghost'. ${ }^{10}$ Moreover, 'for a long time she made the brotherhood anxious and deceived them, accomplishing certain wonderful and portentous things, and promised that she would cause the earth to be shaken'. ${ }^{11}$ This woman showed marks of authority: she was able to walk 'with bare feet over frozen snow, and not to be troubled or hurt in any degree by that walking'; she said that she had come from Judea and Jerusalem. She sanctified the bread and celebrated the eucharist 'with an invocation not to be condemned' (invocatione non contemptibili sanctificare se panem et eucharistiam facere simularet), offered 'sacrifice to the Lord, not without the sacrament of the accustomed utterance' (sacrificium Domino [non] sine sacramento solitae praedicationis offerret: probably the sermon ${ }^{12}$ ), and she baptized many people, laying claim to the usual and lawful words of interrogation, that nothing might seem to be different from the ecclesiastical rule' (baptizaret quoque multos usitata et legitima verba interrogationis usurpans, ut nil discrepare ab ecclesiastica regula videretur). ${ }^{13}$ In

\footnotetext{
7 Ibid. 8.

${ }^{8}$ Ibid. 19. These 'new prophets' were presumably followers of Montanus and Prisca, that is, of the New Prophecy.

${ }^{9}$ Ibid. 7.

${ }^{10}$ Ibid. 10; cf. Ute E. Eisen, Amtsträgerinnen im frühen Christentum. Epigraphische und literarische Studien (Göttingen, 1996), 84-5; ET Women Officebolders in Early Christianity: Epigraphical and Literary Studies (Collegeville, MN, 2000), 72.

11 Cyprian, Ep. 75.10.

12 R. P. C. Hanson, 'The Liberty of the Bishop to improvise Prayer in the Eucharist', VC 15 (1961), 173-6, at 175. The 'non' is missing from the Latin in PL, but commentators are agreed that it is implied by the sense.

13 Cyprian, Ep. 75.10.
} 
short, she looked and behaved like a person who had been moved by the Holy Spirit to prophesy, perform miraculous deeds and celebrate the legitimate sacraments of the Church. Such was her apparent authority, Firmilian reports, that 'one of the presbyters ... and another, a deacon' were convinced by her teachings, and 'associated with' her (ut eidem mulieri commiscerentur). ${ }^{14}$

So what was the problem? Why was doubt suddenly cast on this woman's use of the 'invocation not to be condemned', 'the sacrament of the accustomed utterance' and the 'usual and lawful words of interrogation' at baptism? Firmilian recounts that a local exorcist, 'a man approved and always of good conversation in respect of religious discipline', supported by 'very many brethren who were themselves strong and praiseworthy in the faith', observed that this woman was in fact possessed by a demon, and, 'inspired by God's grace, ... showed that that which was before thought holy, was indeed a most wicked spirit'. ${ }^{15}$ He does not offer any further explanation: we are given no sense of the process of discernment which led to the revelation of demonic possession. But he is clear that this leaves the Church with a problem:

What, then, shall we say about the baptism carried out by this woman, by which a most wicked demon baptized through means of a woman? Do Stephen and they who agree with him approve of this also, especially when neither the symbol of the Trinity nor the legitimate and ecclesiastical words of interrogation were wanting in her? Can it be believed that remission of sins was given, or that the regeneration of this saving bath [i.e. baptism] was properly completed, when all these things, although they had the image of truth, were done by a demon ${ }^{16}$

This episode, Firmilian concludes, demonstrates 'the very deceitfulness of devils, since the Holy Spirit is in no way amongst them'. ${ }^{17}$ And yet these demons have masqueraded as the Holy Spirit, causing

14 Ibid. The meaning of the verb is ambiguous, and could mean either 'had contact with' or 'slept with': see Christine Trevett, 'Spiritual Authority and the "Heretical" Woman: Firmilian's Word to the Church in Carthage', in Jan Willem Drijvers and John W. Watt, eds, Portraits of Spiritual Authority: Religious Power in Early Christianity, Byzantium and the Christian Orient (Leiden, 1999), 45-62, at 57-8.

${ }^{15}$ Cyprian, Ep. 75.10.

16 Ibid. 11.

17 Ibid. 
considerable confusion and uncertainty amongst the faithful. Firmilian appears not a little dismayed that so many had been taken in by their deceitfulness.

Firmilian's account of the ministry of this unnamed woman in the period before she was discerned to be possessed by a devil raises interesting questions about the validity of her ministry, about her ecclesiastical allegiance and about the significance of her gender. The most obvious interpretation is that she was a follower of Montanism. ${ }^{18}$ Andrzej Wypustek points out that until the early twentieth century 'most scholars connected this female miracle-worker with Montanism'; a rare exception was Pierre Labriolle, who argued that her association with Jerusalem and Judea was not consistent with Montanism's focus on Pepuza. ${ }^{19}$ Anne Jensen has followed Labriolle, taking this 'baptizing, eucharist making, prophesying, sign-performing, perhaps ascetic female leader' to be catholic. ${ }^{20}$ However, more recent interpreters have returned to the hypothesis that she was a Montanist. Hanson sees the woman as 'under the influence of Montanism'. ${ }^{21}$ Trevett concludes that - if the woman existed at all (for, she suggests, the woman 'may even have been a composite of various stereotypes and projected fears with regard to the kinds of teachers and teaching she was used to represent') - then she was 'one of those "who are called Cataphrygians and attempt to employ new prophecies," i.e. a Montanist'. ${ }^{22}$

In this reading, the doubtful nature of the baptisms this woman had administered is attributable to the fact that she is associated with a heretical group in which female prophets were known to be active. Trevett argues that Firmilian, writing from Asian Cappadocia, wishes to emphasize to Cyprian, based in North Africa, the real danger of the New Prophecy. ${ }^{23}$ If this is the case, then by implication Firmilian is also highlighting the real difficulty of distinguishing a Montanist prophet from a member of the 'Great Church'. Wy-

\footnotetext{
18 For an introduction to Montanism, see Christine Trevett, Montanism: Gender, Authority and the New Prophecy (Cambridge, 1996).

19 Andrzej Wypustek, 'Magic, Montanism, Perpetua, and the Severan Persecution', VC 51 (1997), 276-97, at 279; cf. P. de Labriolle, La Crise montaniste (Paris, 1913), 487.

20 Anne Jensen, Gottes selbstbewußte Töchter. Frauenemanzipation im frühen Christentum? (Freiburg, Basel and Vienna, 1992), 352-8, especially 357 (ET God's Self-Confident Daughters?: Early Christianity and the Liberation of Women [Louisville, KY, 1996], 182-6).

21 Hanson, 'Liberty of the Bishop', 175.

22 Trevett, 'Spiritual Authority', 45, 50.

23 Ibid. 51-5.
} 
pustek has argued, following Eusebius of Caesarea, that Montanism 'resembled madness' and that it was associated with 'superstition ... the sign of delirium, deliramentum ... [which] to some extent means insanus, insaniens. ${ }^{24}$ However, Montanism was not easy for its contemporaries - including members of the ecclesiastical hierarchy - to identify or to categorize: Tertullian (probably himself by then a sympathizer) asserts that $c .200$, having 'acknowledged the prophetic gifts of Montanus, Prisca and Maximilla', the bishop of Rome wrote a 'letter of peace' to the churches in Asia and Phrygia. A certain Praxeas, however, 'importunately urging false accusations against the prophets themselves and their churches, and insisting on the authority of the bishop's predecessors in the see', persuaded him to recall the letter. ${ }^{25}$ As Nancy Caciola observes: 'There seems to have been little dispute over the fact that Montanus and his followers were possessed by a spirit. Rather, the central issue was the character of that spirit: Holy or demonic? ${ }^{26}$ This is precisely the dilemma that exercises Firmilian. Despite his explicit mention of Montanus and Prisca elsewhere in his letter, Firmilian himself does not make a connection between them and this woman; rather he affirms that she had ministered in accordance with the expected rites of the Church - and yet she had been possessed.

Whether or not she was a Montanist, the unmasked prophetess was certainly a woman. Of what significance was her gender? In Christine Trevett's view, Firmilian's letter provides

a pointer to the developing Christian definition of propriety and impropriety in female behaviour. ... She had been, according to Firmil-

${ }^{24}$ Wypustek, 'Magic, Montanism', 277; cf. Eusebius: '[Montanus] became beside himself, and ... raged in a frenzy and ecstasy, and began to babble and utter strange things': Church History 5.16, as cited by Nancy Caciola, Discerning Spirits: Divine and Demonic Possession in the Middle Ages (New York, 2003), 6-7.

25 Tertullian, Ad Praxean 1.5; cf. Frederick C. Klawiter, 'The Role of Martyrdom and Persecution in Developing the Priestly Authority of Women in Early Christianity: A Case Study of Montanism', ChH 49 (1980), 251-61, at 252. Klawiter sees the authority of the Montanist prophets as arising primarily from their experience as confessors or martyrs, but, as noted above, in Firmilian's context response to persecution does not seem to be the main concern.

26 Caciola, Discerning Spirits, 7. Karen L. King makes a similar point: 'For Christians, the rhetoric was clear: true prophets were inspired by divine agency; false prophets were inspired by the devil and his demons. In practice, however, distinguishing the two was trickier': 'Prophetic Power and Authority: The Case of the Gospel of Mary [Magdalene]', in Beverly Mayne Kienzle and Pamela J. Walker, eds, Women Preachers and Prophets through Two Millennia of Christianity (Berkeley, CA, 1998), 21-41, at 29. 
ian, in the public and not the private sphere, behaving [in a] disorderly [way] and disrupting ordered community, demonically wily and deceitful, usurping the rites of men, and sexually predatory. ${ }^{27}$

Eisen, in contrast, observes: 'Firmilian accuses [the woman] of sexual immorality and of being possessed by a demon, but he does not support his argument by saying that as a woman she has illegitimately laid claim to the charism and the right to celebrate the sacraments', concluding (with Reinhold Seeberg over a century ago) that the fact that Firmilian does not condemn the ministry of this woman because of her sex 'indicates, as does the long prophetic and priestly career of this woman, that women who had a prophetic, liturgical or sacramental function were accepted in Cappadocia in the third century. ${ }^{28}$ Similarly, Klaus Thraede and Anne Jensen argue that Firmilian's account of the affair implies that before the suspicion of possession arose, her ministry had been accepted, and that initially there had been no doubt whatsoever about the validity and effectiveness of her celebrations of the eucharist and her administration of baptism. ${ }^{29}$ Hanson observes that she had 'made herself a church leader' (without reflecting that she could not have done this without the support, or at least the acceptance, of the people to whom she ministered), but concedes that 'this woman could compose a prayer whose style and content were not discreditable. ${ }^{30}$ The implication is that her gender was not initially a decisive factor.

Looking back in this episode with the benefit of hindsight, and knowing that she had been discredited, Firmilian is concerned to define the status of those who had been baptized by someone possessed by a demon, and to resolve the doubts about the validity of these baptisms, but he does not seem at all exercised by the fact that the minister of these baptisms had been a woman. Rather, as David Frankfurter observes, ' $[\mathrm{t}]$ he possessed woman functioned with

27 Trevett, 'Spiritual Authority', 58-9.

28 Eisen, Amtsträgerinnen im frühen Christentum, 85 (Women Officebolders in Early Christianity, 72, amended). Eisen cites Reinhold Seeberg, 'Über das Reden der Frauen in den apostolischen Gemeinden', Deutsch-Evangelisches Jabrbuch 2 (1899), 19-43.

29 Klaus Thraede, 'Ärger mit der Freiheit, Die Bedeutung von Frauen in Theorie und Praxis der alten Kirche', in Gerta Scharffenorth and Klaus Thraede, eds, 'Freunde in Christus werden ...'. Die Beziehung von Mann und Frau als Frage an Theologie und Kirche, Kennzeichen 1 (Gelnhausen and Berlin, 1977), 31-182, at 136; Jensen, Gottes selbstbewußte Töchter, 355 (God's Self-Confident Daughters?, 184); cf. Charlotte Methuen, 'Widows, Bishops and the Struggle for Authority in the Didascalia Apostolorum', JEH 46 (1995), 197-213, at 212.

30 Hanson, 'Liberty of the Bishop', 175. 
considerable authority for some time as the vehicle of a prophetic spirit.' Indeed, Frankfurter suggests that in his letter 'Firmilian tries to balance the spirit's appearance of holiness (i.e., its behavior within the roles expected for holy spirits) with his subsequent recognition of its demonic identity. ${ }^{31}$ In other words, and as Joseph Wright concludes, 'the heart of Firmilian's objection is that the person baptizing is the instrument of a demon, not that she is a woman'. ${ }^{32}$ Trevett also concedes that 'not many decades previously, and still doing the same things, she might simply have been a prophet'. ${ }^{33}$ In Trevett's reading, Firmilian's account of this woman is located in a Church poised on the cusp between accepting that women might exercise a legitimate ministry, ${ }^{34}$ and doubting that this was possible.

This conclusion is consistent with the findings of scholars, including Ute Eisen, Rebecca Lyman, Gary Macy, Kevin Madigan, Carolyn Osiek, Ilaria Ramelli, Karen Jo Torjesen and myself, ${ }^{35}$ that well into the third century, and even into the fourth, women were accepted at least in some parts of the Church - as ministers at the eucharist

31 David Frankfurter, 'Where the Spirits Dwell: Possession, Christianization, and Saints' Shrines in Late Antiquity', HThR 103 (2010), 27-46, at 30.

32 John H. Wright, 'Patristic Testimony on Women's Ordination in Inter Insigniores', Theological Studies 58 (1997), 516-26, at 519.

33 Trevett, 'Spiritual Authority', 59.

34 King argues that 'women's prophetic speech was highly valued in early Christian movements and contributed to the construction of early Christian teaching and practice': 'Prophetic Power and Authority', 32. Karen Jo Torjesen concurs: 'Prophecy was considered a natural role for women in antiquity. ... Second-century Christians familiar with the spirit-inspired worship of churches like that of Corinth would have associated the orans [praying and prophesying with outstretched arms] with women's "liturgical" prophecy': 'The Early Christian Orans: An Artistic Representation of Women's Liturgical Prayer and Prophecy', in Kienzle and Walker, eds, Women Preachers and Prophets, 42-56, at 47.

35 See Eisen, Amtsträgerinnen im frühen Christentum (Women Officeholders in Early Christianity); Rebecca Lyman, 'Women Bishops in Antiquity: Apostolicity and Ministry', in Harriet Harris and Jane Shaw, eds, The Call for Women Bishops (London, 2004), 37-50; Kevin Madigan and Carolyn Osiek, eds, Ordained Women in the Early Church: A Documentary History (Baltimore, MD, 2011); Charlotte Methuen, 'Vidua - Presbytera - Episcopa: Women with Oversight in the Early Church', Theology 108 (2005), 163-77; eadem, 'Die Autorität von Frauen in der Alten Kirche am Beispiel der Syrischen Didascalia', in Leonore SiegeleWenschkewitz, Gury Schneider-Ludorff and Beate-Irene Hämel, eds, Frauen Gestalten Geschichte. Im Spannungsfeld zwischen Religion und Geschlecht (Wiesbaden, 1998), 9-32; Karen Jo Torjesen, When Women were Priests: Women's Leadership in the Early Church and the Scandal of their Subordination in the Rise of Christianity (San Francisco, CA, 1993); Ilaria Ramelli, 'Theosebia: A Presbyter of the Catholic Church', Journal of Feminist Studies in Religion 26 (2010), 79-102. For subsequent developments, see Gary Macy, The Hidden History of Women's Ordination: Female Clergy in the Medieval West (Oxford, 2008). 
and at baptism, as attested by sources including the writings of Tertullian (c.150-220) and Origen (c.185-254), the Didascalia Apostolorum, a Church order composed in Greek probably around 230, and, later, the Council of Laodicea (c.363-4), and supported by inscriptional evidence. $^{36}$ That the ministry of women was not uncontested in this period is also clear, but, as Virginia Burrus has argued, 'the common association of women with heresy that emerges in fourth-century texts is not somehow "found" in the historical context but is rather a symbolic creation'. ${ }^{37}$ Firmilian's account can, therefore, be read as offering evidence that the ministry of women was not viewed as necessarily doubtful in this period, but that women (unless they were possessed by demons) were - at least in some contexts - accepted as presidents at the eucharist and ministers of baptism.

Trevett, Frankfurter and Wright nonetheless suggest that the woman's gender was, at least to some extent, an issue for Firmilian. As we have seen, Trevett (with the benefit of hindsight) suggests that Firmilian defines the woman in categories which would in due course come to be markers of the heretical woman proper'. ${ }^{38}$ Wright suggests that the fact ' $t$ t] hat she is a woman may aggravate the matter in Firmilian's view', although he maintains that her gender 'is not the point of [Firmilian's] objection'. ${ }^{39}$ Frankfurter argues that the 'oscillating perspectives' offered by Firmilian 'were made all the more acute given that the woman was performing sacraments'. ${ }^{40}$ It is not entirely clear on what basis these claims are made, for although Firmilian mentions the fact that the case concerns a woman, he does not comment further on her gender. ${ }^{41}$ Frankfurter is surely right to conclude that 'of most historical significance in this letter is Firmilian's depiction of the real ambiguity of possessing spirits and the imprecision of people's attempts to classify spirits as either "holy" or "demonic / wicked". ${ }^{42}$ His suggestion that "even after the exorcist's

\footnotetext{
36 For a useful summary of the evidence, see Ramelli, 'Theosebia', 87-9; for more detail, Eisen, Amtsträgerinnen im früben Christentum (Women Officeholders in Early Christianity); Madigan and Osiek, eds, Ordained Women.

37 Virginia Burrus, 'The Heretical Woman as Symbol in Alexander, Athanasius, Epiphanius, and Jerome', HThR 84 (1991), 229-48, at 248.

38 Trevett, 'Spiritual Authority', 58.

39 Wright, 'Patristic Testimony', 519.

40 Frankfurter, 'Where the Spirits Dwell', 30.

41 Since no other writings by Firmilian are extant, we do not know whether he discussed these questions elsewhere.

42 Frankfurter, 'Where the Spirits Dwell', 30.
} 
pronouncement there was probably some conflict over the definition of the spirit, reflected in Firmilian's own ambivalent tone' also seems convincing. ${ }^{43}$

The ambiguity about the significance of the woman's gender might be a pointer to a further level of complexity. If such an ambiguity existed after the condemnation - and Frankfurter's reading of Firmilian seems plausible - then it probably existed before, and may well have contributed to the unease about the woman's ministry felt by the exorcist who denounced her. If that is the case, then the original doubts about her ministry may indeed - implicitly, if not explicitly have been associated with her gender. The accusations of demonic possession could then represent an expression of uncertainty about the holiness of these activities when carried out by a woman. That such uncertainty did exist in this period, and that it could be specifically and explicitly related to the ministry of women, can be seen from advice given in the Didascalia Apostolorum:

that a woman should baptize, or that one should be baptized by a woman, we do not counsel, for it is a transgression of the commandment, and a great peril to her who baptizes and to him who is baptized. For if it were lawful to be baptized by a woman, our Lord and Teacher Himself would have been baptized by Mary His mother, whereas He was baptized by John, like others of the people. Do not therefore imperil yourselves, brothers and sisters, by acting beyond the law of the Gospel. $^{44}$

When compared with the Didascalia, it is clear that Firmilian does not condemn the actions of the woman qua woman in the same unequivocal terms. This might, however, imply that in the context in which Firmilian is writing, doubts about the sacramental ministry of a woman qua woman seemed more properly expressed in terms of demonic possession rather than (as in the Didascalia) in terms of her gender. In Firmilian's narrative, the accusation of demonic possession placed the woman at odds with the structures of the Church in a way that her being a woman had not, apparently, initially done. This could well bring us back to Montanism, for it is clear that women were accepted as leaders within that movement, ${ }^{45}$ and Firmilian's letter testifies to

43 Ibid.

44 Didascalia Apostolorum, transl. and ed. by R. Hugh Connolly (Oxford, 1929), 142.

45 Jensen, Gottes selbstbewußte Töchter?, 279 (God's Self-Confident Daughters?, 139). 
the difficulties of distinguishing between it and the catholic Church. He was writing in a context in which the authority of women could be accepted.

As noted at the outset, Firmilian's letter was written as a contribution to a debate about doubt and certainty relating to the sacraments, and particularly to baptism. It is clear that Firmilian's reasons for raising doubts about the baptisms administered by this woman - certainly demonic possession, perhaps her affiliation to the New Prophecy and possibly her gender - are rather different from those raised by Cyprian in the North African context, which centre on behaviour under persecution. In both contexts, however, such doubts seem to have been a factor in the way in which the third-century Church sought better to define itself and its structures and processes.

Firmilian's letter, however, does not merely contribute to our understanding of the role of doubt in the third century. It can also act as a case study illustrating the role of doubt in modern scholarly discourse, and in particular in the expansion of research into the role of women in the early Church. For Firmilian's female prophetess was granted a bit-part in the 1976 encyclical Inter Insigniores, a papal 'declaration on the question of admission of women to the ministerial priesthood', which categorically rejected the possibility of ordaining women to the priesthood on a number of grounds, including that of tradition. In a paragraph which continues to represent the official teaching of the Roman Catholic Church, Inter Insigniores states:

The Catholic Church has never felt that priestly or episcopal ordination can be validly conferred on women. A few heretical sects in the first centuries, especially Gnostic ones, entrusted the exercise of the priestly ministry to women. This innovation was immediately noted and condemned by the Fathers, who considered it as unacceptable in the Church. ${ }^{46}$

Five Fathers are cited as evidence for this 'immediate' condemnation: Irenaeus (Adversus haereses 1.13.2), Tertullian (De praescriptione haereticorum 41.5), Firmilian of Caesarea (Cyprian, Epistola 75), Origen (Fragmentum in 1 Cor. 74) and Epiphanius (Panarion 49.2-3, 78.23;

\footnotetext{
46 Inter Insigniores, $\$ 1$ n. 7, online at: <http://www.papalencyclicals.net/Paul06/ p6interi.htm>, accessed 28 August 2014.
} 
79.2-4). In this way, Inter Insigniores applies Firmilian's doubts about the ministry of the prophetess to an argument about doubt in quite another context: the twentieth-century debate on the ordination of women. Firmilian's uncertainty about the woman's ministry is taken to relate only to her gender, and his letter is read as implying the intrinsic doubtfulness of the ordained ministry, not just of this, but of any woman.

Wright's exploration of Firmilian's attitude towards the woman, discussed above, was written in direct engagement with Inter Insigniores. His article considers the eight patristic passages cited by Inter Insigniores in their context, seeking to reveal the underlying assumptions both of the patristic authors and of Inter Insigniores. He concludes that none of the texts cited in Inter Insigniores is directly relevant to the debate about the ordination of women. Instead, what he found were assumptions about the nature of women which, he claimed (in my view somewhat over-optimistically) had since been rejected by the Church: 'the conviction that women by nature, temperament, and social status are inferior to men'. ${ }^{47}$ He concludes:

It seems to me that if the examples cited by the CDF [Congregation for the Doctrine of the Faith] as the testimony of the Church Fathers are at all representative of what tradition has to offer, we must acknowledge that their testimony offers meager support for the claim that the tradition of not ordaining women was motivated primarily by the Church's intention to remain faithful to the will of Christ. ${ }^{48}$

Wright thus cast doubt upon the interpretation offered by Inter Insigniores. He was not the only scholar to be inspired by the official statements of the Church to examine the sources more closely. Anne

47 Wright, 'Patristic Testimony', 526. As most recently articulated in Mulieris Dignitatem (1988), Roman Catholic teaching holds, not that women are inferior, but that men and women are complementary: 'The personal resources of femininity are certainly no less than the resources of masculinity: they are merely different.' However, the presentation of women as receptive could very easily shade into suggesting that they are inferior: 'the woman is the one who receives love in order to love in return ... This "prophetic" character of women in their femininity finds its highest expression in the Virgin Mother of God. ... the "perfect woman" (cf. Prov 31:10) becomes an irreplaceable support and source of spiritual strength for other people, who perceive the great energies of her spirit': Mulieris Dignitatem, $\$ \$ 10,29,30$, online at: <http://www.vatican.va/ holy_father/john_paul_ii/apost_letters/documents/hf_jp-ii_apl_15081988_mulierisdignitatem_en.html>, accessed 28 August 2014.

48 Wright, 'Patristic Testimony', 526. 
Jensen observed that studies of the role of women in the early Church proliferated as the debate about the ordination of women gained momentum in many denominations during the 1960s and 1970s. Arguments like that presented in Inter Insigniores, that the Church $\mathrm{Fa}$ thers had acted immediately to suppress the ministry of women, began to be questioned by the findings of new research, more attentive both to the complexities of defining heresy and orthodoxy ${ }^{49}$ and to the assumptions about women which had shaped much (although by no means all) earlier scholarship. ${ }^{50}$ Nonetheless, the Vatican's most recent statement about women and ordination, Ordinatio Sacerdotalis (1994), reaffirms its earlier reading, citing 'the constant practice of the Church, which has imitated Christ in choosing only men', and referring to Inter Insigniores as the definitive presentation of the arguments for its position. ${ }^{51}$ This contrasts with references to women's role in the early Church (though not to Firmilian) in Anglican debates, which show some evidence of engagement with recent scholarship. ${ }^{52}$ Such debates offer an example of the way in which a change of assumptions in society can give rise to new questions. ${ }^{53}$ They also suggest that such a historiographical reorientation might be trig-

49 See, for instance, Walter Bauer, Orthodoxy and Heresy in Early Christianity (Philadelphia, PA, 1971); Henry Chadwick, Heresy and Orthodoxy in the Early Church (Aldershot, 1991); Rebecca Lyman, 'Hellenism and Heresy', JECS 11 (2003), 209-22.

${ }^{50}$ Hans Achelis, for instance, one of the translators and editors of a German translation of the Didascalia Apostolorum published in 1904, had no doubt that its author was seeking to suppress the ministry of 'prophetesses empowered by the Spirit' (geistesmächtige Prophetinnen), known as widows, and witnessed to by other early sources: 'The widows, whom the author has in mind, are not weak women but prophetesses empowered by the Sprit.' He comments further: 'Should anyone be surprised by this conclusion, I would point initially to the Apostolic Church Order [a third-century church order] 21 (24): "Three widows are to be appointed, two to devote themselves to prayer on behalf of all those who are tempted and to revelations about whatever is necessary, and one to sit with the women who are sick".' Hans Achelis and Johannes Fleming, Die syrische Didaskalie, Texte und Untersuchungen 25, Neue Folge 10 (Leipzig, 1904), 275 and n. 2. For the widows in the Apostolic Church Order, see also Gillian Cloke, This Female Man of God: Women and Spiritual Power in the Patristic Age, AD 350-450 (London, 1995), 90.

51 Ordinatio Sacerdotalis, online at: <http://www.vatican.va/holy_father/john_paul_ii/ apost_letters/1994/documents/hf_jp-ii_apl_19940522_ordinatio-sacerdotalis_ en.html>, accessed 28 August 2014.

52 See, for instance, Women Bishops in the Church of England? A Report of the House of Bishops' Working Party on Women in the Episcopate (London, 2004), 167-8, albeit for a very brief discussion.

53 Macy, for instance, notes 'how concern over the ordination of women in the present has driven the historical question of whether women had ever been ordained in the past': Hidden History, 21. He also highlights the danger of uncritical assumptions that the term 
gered by growing awareness of - and doubt about - the assumptions which underlie earlier results. Thomas Kuhn posited that the acceptance of scientific 'truth' depends upon the narrative accepted by the scientific community which generates that truth, and that a shift in the interpretative paradigm results from the recognition of anomalies which raise doubts about the underlying assumptions of the existing paradigm. However, he observed, not all interpreters will accept the revised paradigm. ${ }^{54}$ Despite its historiographical shortcomings, Kuhn's model still offers useful insights both into developments in gender history, and into the Churches' various responses to it.

Firmilian was writing at a time in which Church structures, and with them greater clarity - but also greater concern - about who was within and who 'without the Church', 55 were emerging. He appeals to a synod of the Church, but he was puzzled by how to deal with this case of a woman who had appeared to fulfil all the criteria for belonging to, and indeed being authorized by, the Church - the use of the correct words and forms, the respect of some of the clergy but who seemingly turned out to be possessed. The Christian Church of the third century was witnessing a shift from the New Testament dependence on charismatic or spiritual power to a more institutional understanding of power, and Firmilian's letter offers evidence that this development was in part driven by the challenge of resolving doubts about the authenticity of spirits. Introducing a concept of institutional authority into the Church (at least in theory) made it possible to discern where God's grace was truly at work. ${ }^{56}$

'ordination' as it was used in Late Antiquity or the early medieval period can be taken to be congruent with its meaning today: ibid. 15-17, 23-48.

54 Thomas S. Kuhn, The Structure of Scientific Revolutions, 2nd enlarged edn (Chicago, IL, 1970). Kuhn's thesis is, however, based upon a reading of the history of science which has not gone unchallenged: see, for example, J. V. Field, 'On the Revolutions: Copernicus (1543) and Kuhn $(1957,1962,1987)$ ', Bulletin of the Society for Renaissance Studies 5 (1988), 2-6.

55 Cyprian, Ep. 75.19.

56 For a North African case study examining similar questions in relation to Perpetua, Felicitas and Cyprian, see Charlotte Methuen, "I, who knew that I was privileged to converse with the Lord ...": Christian Women and Religious Authority in Third-Century North Africa', Modern Believing 54 (2013), 23-33. Caciola identifies in the high Middle Ages 'a practice of institutionalised mistrust regarding individual claims to visionary or prophetic authority' and traces the ongoing difficulty that this process of discernment caused for the medieval Western Church, exploring 'how the testing of spirits was coded and recoded in response to changing social, cultural and religious currents of the late twelfth through fifteenth centuries': Discerning Spirits, quotations at 1-2. For this process 
In general, women were excluded by these developments from exercising a recognized ministry within the Church, and ever greater doubts were expressed about their capability of experiencing God in any way other than through direct revelation. ${ }^{57}$ Consequently, in the medieval Western Church, such spiritual authority as women were able to exercise - with the occasional exception of those who held high office in a convent - was of necessity charismatic authority. Women received visions, the nature of which was always doubtful, so that the visions, together with the women who experienced them, were rigorously tested by the hierarchy of the Church in order to discern whether they were of the Spirit or the result of possession. Firmilian's uncertainty about the status of the spirits was shared by the later hierarchy. His initial acceptance of the authenticity of this woman's ministry was not. It would be more than sixteen hundred years before any Western Christian author could report as matter-of-factly as Firmilian that a woman had celebrated the eucharist, preached and administered baptism; the Church of England's decision to admit women to the episcopate (with continuing provisos for the minority who have doubts about the legitimacy of this decision) was made while this essay was being written. And the Roman Catholic Church continues to hold that the validity of the ordained ministry of women is inherently doubtful - citing Firmilian to sustain a position with which he might well have profoundly disagreed.

\footnotetext{
and its historiographical repercussions for interpreting the contribution of women, see Anke E. Passenier, 'Der Lustgarten des Leibes und die Freiheit der Seele. Wege der Mittelalterlichen Frauenspiritualität', in: Elisabeth Hartlieb and Charlotte Methuen, eds, Sources and Resources of Feminist Theologies, European Society for Women in Theological Research Yearbook 5 (Mainz, 1997), 244-65; Charlotte Methuen, 'Mystikerinnen im Mittelalter: Theologie einer weiblichen Gotteserfahrung?', in Elzbieta Adamiak and Marie-Theres Wacker, eds, Feministische Theologie in Europa - Mehr als ein Halbes Leben. Ein Lesebuch für Hedwig Meyer-Wilmes, Theologische Frauenforschung in Europa 25 (Munster, 2013), 12641.

57 For evidence that some women continued nonetheless to exercise ministries of leadership, cf. Eisen, Amtsträgerinnen im frühen Christentum (Women Officebolders in Early Christianity); Methuen, 'Vidua - Presbytera - Episcopa'; Macy, Hidden History; Joan Morris, Against Nature and God: The History of Women with Clerical Ordination and the Jurisdiction of Bishops (London and Oxford, 1973), also published as The Lady was a Bishop: The Hidden History of Women with Clerical Ordination and the Jurisdiction of Bishops (New York and London, 1973).
} 